\title{
Could the directly measured data of transpiration be replaced by model outputs?
}

\author{
Hana STŘEDOVÁ ${ }^{1,2, *}$, Jana KLIMEŠOVÁ ${ }^{1}$, Tomáš STŘEDA ${ }^{1,2}$, \\ Petra FUKALOVÁ ${ }^{1}$ \\ ${ }^{1}$ Faculty of AgriSciences, Mendel University in Brno, \\ Zemědělská 1665/1, 61300 Brno, Czech Republic \\ ${ }^{2}$ Department of Meteorology and Climatology, Czech Hydrometeorological Institute, \\ Brno Branch, Kroftova 43, 61667 Brno, Czech Republic
}

\begin{abstract}
Successful upscaling of the direct measurement of evapotranspiration at individual plant level to canopy level with specific microclimatic conditions has recently received considerable attention of scientific community. And since the knowledge of transpiration is among important inputs of various experiments on solitary plant level the paper employs the reverse approach - the downscaling from the canopy to individual plant. The main task of the study is thus to compare Penman-Monteith method of computing potential evapotranspiration with directly measured values of transpiration of maize. Since the model deals with canopy level and the direct measurement is being carried out on level of individual plants, this comparison answers the question if the timeconsuming and demanding measurement of transpiration on plant level could be substitute by relative easily reachable model outputs. The results shown that evapotranspiration of maize computed by Penman-Monteith model cannot be successfully downscaled back to the solitary plant level. The correlation coefficient between these two data series for three individual phenological stages vary from 0.5831 to $0.7803(\alpha=0.01)$ while for whole growing period regardless phenological stage is $0.6925(\alpha=0.01)$. The directly measured data of transpiration cannot by simply replaced by modelled data, but their application after conversion using regression equations is possible with certain level of inaccuracy.
\end{abstract}

Key words: maize, sap flow, stem heat balance, transpiration model, the Czech Republic, Penman-Monteith

\section{Introduction}

Changes in transpiration values, which are strongly dependent on meteo-

* corresponding author: e-mail: hana.stredova@mendelu.cz 
rological variables, are induced in accordance with the plant's phenological stage (Pivec et al., 2009), the water levels in the soil (Irmak and Mutiibwa, 2010) or the water potential of the leaves (Li et al., 2002).

Several methods have been used to determine transpiration from individual plants, including tracer measurements for calculations of the sap flow velocity and porometer measurements of leaf transpiration for estimation of the stomatal conductance. Direct measurements of evapotranspiration with using of weighing lysimeters or eddy covariance are difficult to install and operate although they provide the most realistic and accurate data.

Transpiration is closely related to water flow in the xylem (sap flow). Therefore, methods for the evaluation of sap flow may be used to measure either the water consumption of plants (Bethenod et al., 2000) or the stomatal conductivity at the leaf or plant level (Ewers et al., 2007). Methods for sap flow measurement are based on the physical characteristics of water and employ the heat transferred by water contained in the xylem. The "heat pulse method" involves measurement of the gradual speed of flow of a short pulse of heat in the stem or trunk (Cohen et al., 1988; Green, 1993). The "thermal dissipation method" is based on the difference between the temperature of a heated indicator and another sensor, which is influenced by the rate of sap flow (Granier, 1985). The "Stem Heat Balance" method SHB (Lindroth et al., 1995; Smith and Allen, 1996; Kučera et al., 1977) involves direct electrical warming of tissues and internal measurement of temperature. This method may be applied to crops with larger stem diameters (Cohen and Li, 1996), such as maize and sunflower (Ishida et al., 1991), oilseed rape (Merta et al., 2001; Pivec et al. 2011) or cotton (Ham et al., 1990; Dugas et al., 1994). The effect of soil water shortages on plant transpiration, as evaluated by measuring xylem sap flow, has been described by Bethenod et al. (2000), Jara et al. (1998), Gavloski et al. (1992) and Sameshima et al. (1995), among others. Jara et al. (1998) confirmed that the sap flow measurement method is able to detect differences in water consumption by plants grown under different irrigation regimes as well as field conditions. In short, several studies have shown that sap flow measurements with stem heat balance methods agree well with the results of gravimetric techniques. Sap flow measurement is therefore a suitable method for detecting changes in transpiration at the plant level. Long-term sap flow measurements may be used to help develop models of the (evapo)transpiration response to en- 
vironmental variables, as well as crop simulation models, irrigation models etc.

Frequently used Penman-Monteith equation (e.g. equation with stomatal conductance measurement; Zhang et al., 1997) pro various uses and various plant species have been confronted with direct measurement of sap flow. A fairly good match between calculated and measured results in terms of their correlation is usually reported, except for several episodes. Nevertheless, the Penman-Monteith model needs auxiliary sub-models or parameterizations for the stomatal conductances and need local calibrations.

Plants are widely separated in many agronomic, agroforestry, horticultural and forestry situations and are best considered as isolated plants or as rows of plants. It is of practical and theoretical interest to understand the controls on the transpiration rate of single plants. Models based on Monteith (1965), including the Penman-Monteith equation as parameterized by the FAO-56 bulletin (Allen et al., 1998) to compute grass reference evapotranspiration, being derived from canopy do not reflect the real situation of solitary plant. It thus limits their relevance for detail experiments carried out on solitary plant level, such as various laboratory or pot experiments. Stand microclimate, mainly of dense seeded crops usually significantly differs from pot experiments climate (Streda et al., 2011; Krčmářová et al., 2016).

To obtain the precise a detail data on transpiration (e.g. 10-minute interval) in experiments on solitary plant level (not on canopy level) is necessary to measure it in various regimes and sufficient number of plants due to stemto-stem variability in sap flow, preferably under standard stand conditions. The sap flow measurement itself should also be accompanied with measuring of many environmental and biological variables. Ideal is continuous measurement throughout wide range of phenological stages, including the generative period and senescence of the plant not only during short (several days duration) periods.

The measurements of sap flow from individual stems need to be upscaled with the using of sophisticated upscaling functions to derive the transpiration of the entire stand. It is therefore of both scientific and practical importance to develop an accurate upscaling method for extrapolating measured stem-level transpiration to the entire crop community (Duan et al., 2017).

A common approach to simulate crop evapotranspiration is the crop co- 
efficient technique presented in FAO-56 bulletin (Allen et al., 1998). Crop coefficient curves can be developed as a function of time, plant growth stage, thermal unit or growing degree days (GDD), and leaf area index or canopy cover (Martel et al., 2018). To top it all there are inter varietal differences of crop coefficient. It limits the relevance of the method for precise experiments. For example $X u$ et al. (2018) found out seasonal crop coefficients at initial stage, mid-stage and late stage 0.46, 1.53, 1.22 and 0.44, 1.40, 1.09 for large-sized variety and small-sized variety of maize, respectively. It should be taken more into account especially for sizing of irrigation, calculation of water supply in the soil, crop growth models, crop yield models etc. In addition, Anapalli et al. (2016) observed, that crop coefficients calculated with measured evapotranspiration and the short grass or alfalfa crop reference evapotranspiration methods varied from year to year.

Nevertheless, Pereira et al. (2006) deployed concept, that if soil water is not limiting, the transpiration will be conditioned by the leaf area without the need of a crop coefficient. Canopy transpiration of irrigated orchard apple trees, olives, grapevines, and an isolated walnut tree was reliably estimated through the use of the conventional grass reference evapotranspiration parameterized by the FAO-56 bulletin (Allen et al., 1998) corrected only by the canopy leaf area.

Since detail transpiration measurement by stem heat balance method is expensive and time-consuming method and at the same time the knowledge of transpiration is among important inputs of various experiments on solitary plant level there is the following question erasing: Could the modelled evapotranspiration data on canopy level be successfully use for precise biological experiments on solitary plant level? By other words, could they be successfully downscaled back to the plant level?

We should be aware, that in order to validate any model of (evapo)transpiration by its direct measurements by lysimeters, evapometers and or by stem heat balance sensors they must be placed in the same surrounding canopy on sufficiently large piece of land. However the reverse approach i.e. downscaling from the modelled canopy (evapo)traspiration to the solitary plant level should not respect this condition, because the experiments on this solitary level are being conducted beyond canopy (in pot experiments, laboratories, driven environment in phytotrons etc.). 


\section{Materials and methods}

\subsection{Experiment design}

The experiment set comprised six particular plants of maize (line 2087 - the breeding materials of CEZEA Cejč) in three different meteorological years of the last decade. The years under investigation were selected in terms of evapotranspiration demands of atmosphere expressed by vapor pressure deficit (VPD): the year characterized by the highest values of VPD - "the dry year", the year with the medium values - "the normal year" and with the lowest values - "the wet year". The experiment itself was carried out using outdoor pot trials in the climate conditions of South Moravia (the Czech Republic). Six maize plants were sown in pot (size $0.4 \mathrm{~m}^{2}$ and volume of $200 \mathrm{dm}^{3}$ ). Based on pedological analysis and continuous monitoring of soil moisture the available water holding capacity (AWHC) had permanently been maintained on the level of $90 \%$ since $\mathrm{BBCH} 40$ phase i.e. development of harvestable vegetative plant parts (the $\mathrm{BBCH}$ scale is a internationally recognized system for a uniform coding of growth stages of plant species; Meier, 1997). Volume soil moisture [\%] at the depth of 10-40 cm and soil water potential [bar] were measured throughout the experiment.

\subsection{Direct measurement of transpiration on the plant level (Ea)}

Transpiration $\left(\mathrm{Ea}, \mathrm{mm} \cdot \mathrm{h}^{-1}\right.$ ) was monitored by continuous measurement of xylemic sap flow in a 10-minute interval. The measurement system uses the non-destructive method "Stem Heat Balance" (SHB). The measuring system consists of a pair of thermocouples that are installed at a precise distance from each other on the plant stem. For plant species with a thin stem, an external heater is used in the upper thermocouple, and the temperature change is measured by an internal needle sensor in both thermocouples. At the point of thermocouples the stem is insulated with a cylindrical seal all over the perimeter. The entire system is protected from sunlight and rain by an aluminum cover. The electronic system maintains a constant temperature difference $\mathrm{dT}$ (while the power $\mathrm{P}$ is then proportional to the current intensity) (Kučera et al., 1977; Ishida et al., 1991). The heat supplied to the stem is drained by the flow of water in the xylem. At the same time, heat losses occur though. These losses can be derived by measuring the current transpiration flow under the rain or before the dawn and are included 
in the calculation equations. The values of the transpiration flow $(\mathrm{Q})$ are given in units $\left[\mathrm{kg} \cdot \mathrm{h}^{-1}\right]$ and converted to a surface area of $1 \mathrm{~m}^{2}\left(\mathrm{Ea}, \mathrm{mm} \cdot \mathrm{h}^{-1}\right)$ according to canopy density in the pot experiment. The plants from $\mathrm{BBCH}$ 60 (flowering) until BBCH 89 (full maturity) were measured.

\subsection{Modelling of the evapotranspiration on the canopy level (ETo)}

At the effective height of the stand (i.e. $0.68 \times$ actual height with extreme values of 0.53 to 0.86 (Mölder et al., 1999) solar radiation is transformed into other kinds of energy (Hurtalová et al., 2003; Matejka and Huzulák, 1987; Matejka et al., 2002), which has a significant impact on the temperature and humidity regime. The following meteorological elements were measured directly between plants at the effective height level, i.e. $0.68 \times$ plant height:

- Average relative air humidity [\%];

- Average air temperature $\left[{ }^{\circ} \mathrm{C}\right]$;

- Duration of solar radiation [hours];

- Average wind velocity $\left[\mathrm{m} \cdot \mathrm{s}^{-1}\right]$.

Based on this data the daily values of reference (potential) evapotranspiration of maize canopy were computed according to Penman-Monteith model (canopy parameters: height $=2 \mathrm{~m}$; albedo $=0.3$; stomatal conductivity $\left.=100 \mathrm{~m} \cdot \mathrm{s}^{-1}\right)$. Reference evapotranspiration was computed according to FAO methodology (Allen et al., 1998) that is based on modified PenmanMonteith equation.

Data sap flow, i.e. the intensity of transpiration and meteorological data (average air temperature, average value of global radiation etc.), was always evaluated only for the day-time from sunrise to sunset (diurnal data).

\subsection{Data evaluation}

The growing period was divided into three particular periods on the basis of relative unique phenological phases:

- $1^{\text {st }}$ period: BBCH 63-65 (flowering).

- $2^{\text {nd }}$ period: BBCH 65-75 (full flowering - development of fruit). 
- $3^{\text {rd }}$ period: $\mathrm{BBCH} 75-85$ (ripening; $\mathrm{BBCH} 85$ - kernels yellowish to yellow, about $55 \%$ dry matter).

\section{Results and discussion}

Average daily values, which create the basis of evaluation, were calculated from continuously measured data. The following figures (Figs. 1-3) show the both model (ETo) and measured (Ea) transpiration in terms of meteorological parameters: global radiation, vapour pressure deficit (VPD). It was assessed separately for each year divided into the three periods with regard to the different course of transpiration depending on the plant growth phase.

Previous partial research of Klimešová et al. (2013) was focused on finding out the degree of influence of key agrometeorological elements on transpiration. Significant relationships among transpiration, global radiation and air temperature were found.

Relationship between measured transpiration Ea and model transpiration ETo was expressed by correlation coefficient. Correlation in first period $\mathrm{r}=0.936(\alpha=0.01)$ for "the dry year", $0.705(\alpha=0.05)$ for "the normal year" and $0.935(\alpha=0.01)$ for "the wet year". In the second period $\mathrm{r}=0.817$

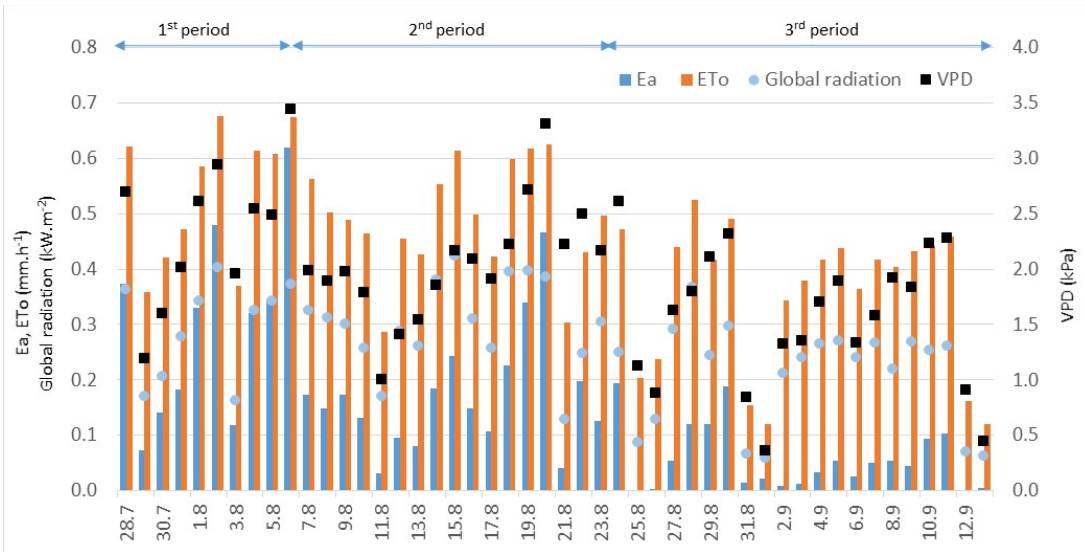

Fig. 1. Course of daily Ea and ETo $\left(\mathrm{mm} \cdot \mathrm{h}^{-1}\right)$ and global radiation and vapor pressure deficit (VPD) for three phenological periods in "dry year". 


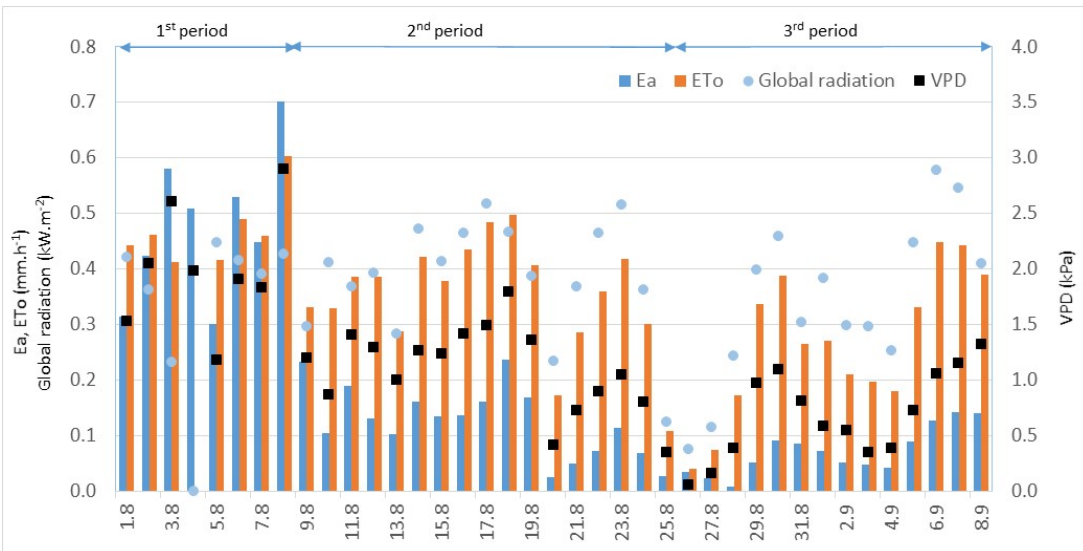

Fig. 2. Course of daily Ea and ETo $\left(\mathrm{mm} \cdot \mathrm{h}^{-1}\right)$ and global radiation and vapor pressure deficit (VPD) for three phenological periods in "normal year".

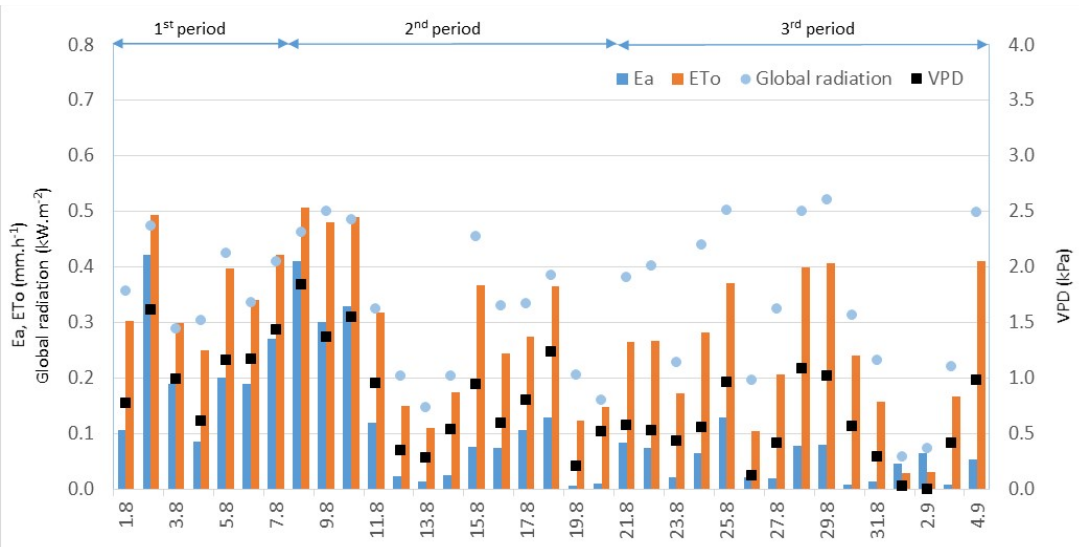

Fig. 3. Course of daily Ea and ETo $\left(\mathrm{mm} \cdot \mathrm{h}^{-1}\right)$ and global radiation and vapor pressure deficit (VPD) for three phenological periods in "wet year".

( $\alpha=0.01)$ for "the dry year", $\mathrm{r}=0.750(\alpha=0.01)$ for "the normal year", $\mathrm{r}=0.924(\alpha=0.01)$ for "the wet year". In the third period $\mathrm{r}=0.714$ ( $\alpha=0.01)$ for "the dry year", $\mathrm{r}=0.869(\alpha=0.01)$ for "the normal year" and $\mathrm{r}=0.531(\alpha=0.05)$ for "the wet year" (combined Fig. 4$)$. 

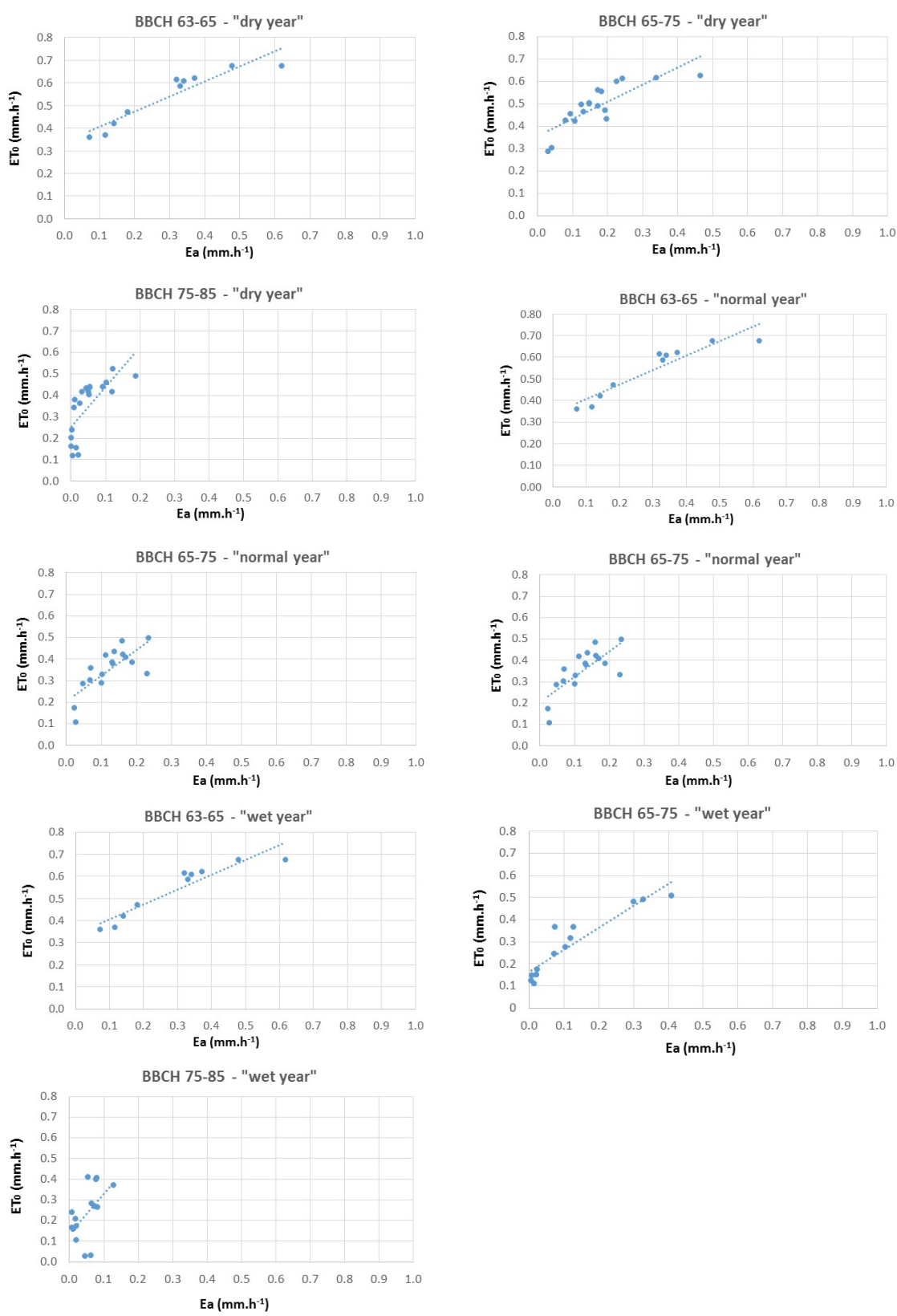

Fig. 4. Relationship between Ea and ETo $\left(m m \cdot h^{-1}\right)$ for three individual phenological stages in three years. 
Average Ea and ETo $\left(\mathrm{mm} \cdot \mathrm{h}^{-1}\right)$ values from three-year period were evaluated for three phenological periods is shown in Fig. 5.

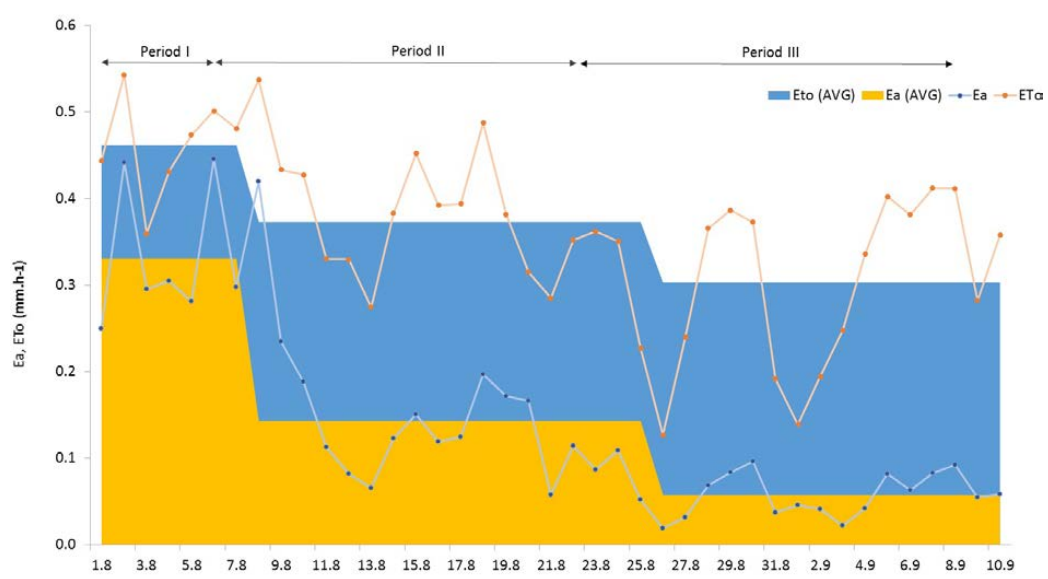

Fig. 5. Three-year average course of Ea and ETo $\left(\mathrm{mm} \cdot \mathrm{h}^{-1}\right)$ and their average values for three phenological periods.

Based on the regression dependence between modelled and measured transpiration, the relationships (combined Fig. 6) and dependence rate (Table 1) were derived.
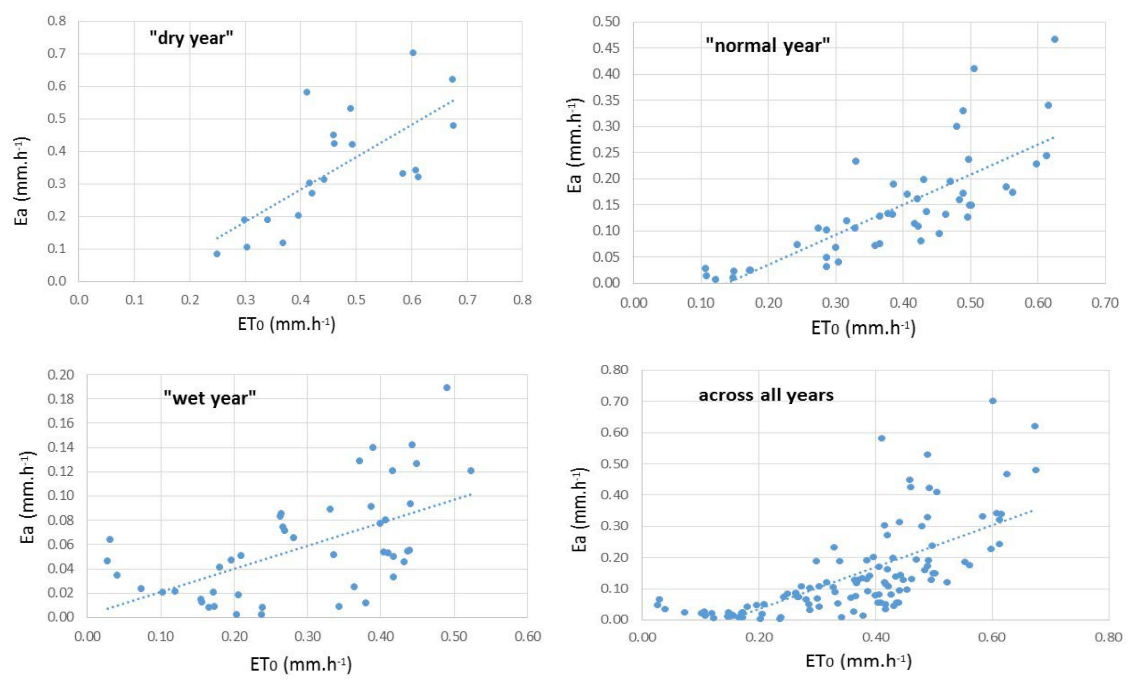

Fig. 6. Relationship between ETo a Ea. 
Table 1. The conversion equations the level of significance.

\begin{tabular}{|l|c|c|}
\hline & conversion equation & correlation coefficient $(\mathbf{r})$ \\
\hline year & $\mathrm{Ea}=0.6713 \mathrm{ETo}-0.0990$ & $0.6925^{* *}$ \\
\hline $1^{\text {st }}$ period & $\mathrm{Ea}=0.9943 \mathrm{ETo}-0.1146$ & $0.7124^{* *}$ \\
\hline $2^{\text {nd }}$ period & $\mathrm{Ea}=0.5739 \mathrm{ETo}-0.0795$ & $0.7803^{* *}$ \\
\hline $3^{\text {rd }}$ period & $\mathrm{Ea}=0.1902 \mathrm{ETo}+0.0021$ & $0.5831^{* *}$ \\
\hline
\end{tabular}

${ }^{* *}$ statistically very significant $(\alpha=0.01)$

On the basis of conversion equation the modification of modelled values for each phenological period was determined (Table 2).

Table 2. Conversion table between ETo and Ea (modification).

\begin{tabular}{|c|c|c|c|c|}
\hline \multirow{2}{*}{ ETo } & \multicolumn{5}{|c|}{ Ea } \\
\cline { 2 - 5 } & year & $\mathbf{1}^{\text {st }}$ period & $\mathbf{2}^{\text {nd }}$ period & $\mathbf{3}^{\text {rd }}$ period \\
\hline 0.0 & 0.00 & 0.00 & 0.00 & 0.00 \\
\hline 0.2 & 0.04 & 0.08 & 0.04 & 0.04 \\
\hline 0.4 & 0.17 & 0.28 & 0.15 & 0.08 \\
\hline 0.6 & 0.30 & 0.48 & 0.26 & 0.12 \\
\hline 0.8 & 0.44 & 0.68 & 0.38 & 0.15 \\
\hline 1.0 & 0.57 & 0.88 & 0.49 & 0.19 \\
\hline
\end{tabular}

The applicability of a lot of alternative models for evaporation and transpiration calculation is usually restricted to specific geographical locations and climatic regimes, because their parameters are derived from experiments employed at the local scale (Tegos et al., 2013).

The Penman-Monteith (PM) model and the Direct Method (DM) model are two of the most widespread transpiration models. Penman-Monteith model was primarily developed for crops grown in open field conditions. For each model, the values of meteorological variables such as air temperature, air humidity, solar radiation, as well as key plant characteristics, (e.g. leaf temperature for DM model) are needed to estimate crop transpiration.

According to Morille et al. (2013) study focused on usage of the PM model, the location of the meteorological parameters used to implement the model is a key factor that affects the results. The study demonstrates that the temperature and humidity considered in the PM model should be taken inside the crop and not above the crop, leading to a so-called PM-Like (PML) model. The PM-Like and the DM models, in a one-layer configura- 
tion, give similar results and are in agreement with actual measurements. The PM model could even be successfully applied under greenhouse conditions, provided that some adjustments are made (thus defining the PMModified model).

The necessity of modifying the model is also desirable on the basis of proven differences in meteorological data measured at a standard climatic station and in a canopy, resp. monitoring of microclimate and microclimate. Krčmářová et al. (2016), who, among other things, investigated the relationship between the relative humidity in the wheat canopy and calculated or measured meteorological values pointed out the necessity of continual canopy microclimate monitoring as well as complicatedness of canopy microclimate modelling. The prediction of air humidity in a wheat canopy cannot be based on data measured at standard climatological stations, as it has not been proven that there is a statistically strong dependence.

\section{Conclusion}

One of the most used transpiration model are Penman-Monteith model that was primarily developed for crops grown in open field conditions. In addition to the models, transpiration can be determined by direct measurement. However, these measurements are very technically demanding. The main task of the paper was to compare Penman-Monteith modelled values of evapotranspiration with directly measured transpiration values of the pot maize experiment.

Measuring of transpiration flow (sap flow) is a possible method for flow water quantification by plants in dependence on environmental factors while respecting the microclimatic specifics With regard to the phenological development of crops, it is appropriate to divide the growth period into partial periods.

The results show that it is not appropriate to use modelled values for single plant experiments without modification. Nevertheless, the conversion of the modified modelled values to single plant level is possible with statistically very significant level of reliability.

Since the conversion equations provided by this paper were derived from the pot measurement they can only be successfully used for the experiments carried out beyond canopy. 
Acknowledgements. The paper was supported by the Ministry of Agriculture of the Czech Republic, Project No. QK1720285 "New methods for adjustment of altered crop water requirements in irrigation systems across Czechia as affected by soil and climate changes".

\section{References}

Allen R. G., Pereira L. S., Raes D., Smith M., 1998: Crop evapotranspiration: guidelines for computing crop water requirements. Irrigation and Drainage Paper No. 56. FAO, Rome, Italy, 300 p.

Anapalli S. S., Ahuja L. R., Gowda P. H., Ma L., Marek G., Evett S. R., Howell T. A., 2016: Simulation of crop evapotranspiration and crop coefficients with data in weighing lysimeters. Agric. Water Manag., 177, 274-283, doi: 10.1016/j.agwat.2016. 08.009 .

Bethenod O., Katerji N., Goujet R., Bertolini J. M., Rana G., 2000: Determination and validation of corn crop transpiration by sap flow measurement under field conditions. Theor. Appl. Climatol., 67, 3-4, 153-160, doi: 10.1007/s007040070004.

Cohen Y., Fuchs M., Falkenflug V., Moreshet S., 1988: Calibrated heat pulse method for determining water uptake in cotton. Agron. J., 80, 3, 398-402, doi: 10.2134/agron j1988.00021962008000030004x.

Cohen Y., Li Y., 1996: Validating sap flow measurement in field-grown sunflower and corn. J. Exp. Bot., 47, 11, 1699-1707, doi: 10.1093/jxb/47.11.1699.

Duan L., Li Y., Yan X., Liu T., Wan X., 2017: Upscaling Stem to Community-Level Transpiration for Two Sand-Fixing Plants: Salix gordejevii and Caragana microphylla. Water, 9, 5, doi : 10.3390/w9050361.

Dugas W. A., Heuer M. L., Hunsaker D., Kimball B. A., Lewin K. F., Nagy J., Johnson M., 1994: Sap flow measurements of transpiration from cotton grown under ambient and enriched $\mathrm{CO}_{2}$ concentrations. Agric. For. Meteorol., 70, 1-4, 231-245, doi: 10.1016/0168-1923(94)90060-4.

Ewers B. E., Mackay D. S., Samanta S., 2007: Interannual consistency in canopy stomatal conductance control of leaf water potential across seven tree species. Tree Physiol., 27, 1, 11-24, doi: 10.1093/treephys/27.1.11.

Gavloski J. E., Whitfield G. H., Ellis C. R., 1992: Effect of restricted watering on sap flow and growth in corn (Zea mays L.). Can. J. Plant Sci., 72, 2, 361-368, doi: 10.4141/cjps92-040.

Granier A., 1985: Une nouvelle méthode pour la mesure du flux de sève brute dans le tronc des arbres. Ann. For. Sci., 42, 2, 193-200, doi: 10.1051/forest:19850204 (in French).

Green S. R., 1993: Radiation balance, transpiration and photosynthesis of an isolated tree. Agric. For. Meteorol., 64, 3-4, 201-221, doi : 10.1016/0168-1923(93)90029-H.

Ham J. M., Heilman J. L., Lascano R. J., 1990: Determination of soil water evaporation and transpiration from energy balance and stem flow measurements. Agric. For. Meteorol., 52, 3-4, 287-301, doi : 10.1016/0168-1923(90) 90087-M. 
Hurtalová T., Matejka F., Janouš D., Rožnovský J., 2003: Influence of a spruce forest stand on the flowing and air temperature and moisture vertical stratification. In: Rožnovský J., Litschmann, T. (Eds.): Workshop "Mikroklima porost", Brno, March 26, 2003, ISBN 80-86690_05-9, 66-79 (in Slovak with English summary).

Ishida T., Campbell G. S., Calissendorff C., 1991: Improved heat balance method for determining sap flow rate. Agric. For. Meteorol., 56, 1-2, 35-48, doi : 10.1016/0168 -1923(91) 90103-W.

Irmak S., Mutiibwa D., 2010: On the dynamics of canopy resistance: Generalized linear estimation and relationships with primary micrometeorological variables. Water Resour. Res., 46, 8, W08526, doi : 10.1029/2009WR008484.

Jara J., Stockle C. O., Kjelgaard, J., 1998: Measurement of evapotranspiration and its components in a corn (Zea Mays L.) field. Agric. For. Meteorol., 92, 2, 131-145, doi : 10.1016/S0168-1923(98)00083-5.

Klimešová J., Středa T., Středová H., 2013: Maize transpiration in response to meteorological conditions. Contrib. Geophys. Geod., 43, 3, 225-236, doi: 10.2478/congeo -2013-0014.

Krčmářová J., Pokorný R., Středa T., 2016: The course, stratification and possibility of simulating relative air humidity in winter wheat stand. Contrib. Geophys. Geod., 46, 2, 137-154, doi : 10.1515/congeo-2016-0010.

Kučera J., Čermák J., Penka M., 1977: Improved thermal method of continual recording the transpiration flow rate dynamics. Biol. Plant., 19, 6, 413-420, doi: 10.1007/BF 02922976.

Li Y., Fuchs M., Cohen S., Cohen Y., Wallach R., 2002: Water uptake profile response of corn to soil moisture depletion. Plant Cell Environ., 25, 4, 491-500, doi: $10.1046 / j .1365-3040.2002 .00825 . x$.

Lindroth A., Čermák J., Kučera J., Cienciala E., Eckersten H., 1995: Sap flow by heat balance method applied to small size Salix trees in a short-rotation forest. Biomass Bioenergy, 18, 1, 7-15, doi: 10.1016/0961-9534(94)00085-8.

Martel M., Glenn A., Wilson H., Kröbel R., 2018: Simulation of actual evapotranspiration from agricultural landscapes in the Canadian Prairies. J. Hydrol. Reg. Stud., 15, 105-118, doi : 10.1016/j.ejrh.2017.11.010.

Matejka F., Huzulák J., 1987: Analysis of the microclimate of the stand (Analýza mikroklímy porastu). Bratislava: VEDA, 232 p. (in Slovak).

Matejka F., Rožnovský J., Hurtalová T., Janouš D., 2002: Effect of soil drought on evapotranspiration of a young spruce forest. J. For. Sci., 48, 4, 166-172, doi : 10.17221 /11871-JFS.

Meier U., 1997: BBCH-Monograph. Growth stages of plants - Entwicklungsstadien von Pflanzen - Estadios de las plantas - D'eveloppement des Plantes. Blackwell Wissenschaftsverlag, Berlin und Wien, 622 p.

Merta M., Sambale C., Seidler C., Peschke G., 2001: Suitability of plant physiological methods to estimate the transpiration of agricultural crops. J. Plant Nutr. Soil Sci., 164, 1, 43-48, doi : 10.1002/1522-2624(200102) 164: 1<43: :AID-JPLN43> 3.0. CO;2-W. 
Mölder M., Grelle A., Lindroth A., Halldin S., 1999: Flux profile relationships over aboreal forest — roughness sublayer corrections. Agric. For. Meteorol., 98-99, 645-658, doi : 10.1016/S0168-1923(99)00131-8.

Monteith J. L., 1965: Evaporation and Environment. Symposia of the Society for Experimental Biology, 19, 205-234.

Morille B., Migeon C., Bournet P. E., 2013: Is the Penman-Monteith model adapted to predict crop transpiration under greenhouse conditions? Application to a new Guinea Impatiens crop. Sci. Hortic., 152, 80-91, doi : 10.1016/j . scienta. 2013.01 .010 .

Pivec J., Brant V., Bečka D., 2009: The influence of weather conditions on the sap flow of Brassica napus L. during the fructification and maturation stages. Ekológia, 28, 1, 43-51, doi: 10.4149/ekol_2009_01_43.

Pivec J., Brant V., Bečka D., Cihlář P., 2011: Consumptive use of water in Brassica napus L. from flowering to ripening stage under rainless region conditions. Irrig. Drain., 60, 4, 493-498, doi : 10.1002/ird.598.

Pereira A. R., Green S., Nova N. A. V., 2006: Penman-Monteith reference evapotranspiration adapted to estimate irrigated tree transpiration. Agric. Water Manag., 83, 1-2, 153-161, doi: 10.1016/j.agwat.2005.11.004.

Sameshima R., Sakuratani T., Takenouchi A., 1995: Relationship between transpiration rate of soybean plants (Glycine $\max$ Merr. cv. Enrei) and soil water content estimated by stem heat balance and heat probe methods. J. Agric. Meteorol., 51, 2, 153-157, doi: 10.2480/agrmet.51.153.

Smith D. M., Allen S. J., 1996: Measurement of sap flow in plant stems. J. Exp. Bot., 47, 12, 1833-1844, doi: 10.1093/jxb/47.12.1833.

Středa T., Středová H., Rožnovský J., 2011: Orchards microclimatic specifics. In: Šiška B., Hauptvogl M., Eliašová M. (Eds.): Bioclimate: Source and Limit of Social Development, International Scientific Conference, 6th - 9th September 2011, Topol'čianky, Slovakia. Nitra: Slovak University of Agriculture in Nitra, 132-133.

Tegos A., Efstratiadis A., Koutsoyiannis D. A., 2013: A parametric model for potential evapotranspiration estimation based on a simplified formulation of the PenmanMonteith equation. In: Alexandris S. (Ed.): Evapotranspiration - An Overview. Chapter: 8, InTech, Rijeka, Croatia, 143-165, doi : 10.5772/52927.

Xu G., Xue X., Wang P., Yang Z., Yuan W., Liu X., Lou Ch., 2018: A lysimeter study for the effects of different canopy sizes on evapotranspiration and crop coefficient of summer maize. Agric. Water Manag., 208, 1-6, doi : 10.1016/j.agwat.2018.04.040.

Zhang H., Simmonds L. P., Morison J. I. L., Payne D., 1997: Estimation of transpiration by single trees: comparison of sap flow measurements with a combination equation. Agric. For. Meteorol., 87, 2-3, 155-169, doi: 10.1016/S0168-1923(97)00017-8. 